\title{
Effect of Cutting and Storage on Acetate and Nonacetate Esters in Convenient, Ready-to-eat Fresh-cut Melons and Apples
}

\author{
John C. Beaulieu ${ }^{1}$ \\ U.S. Department of Agriculture, Agricultural Research Service, Southern Regional Research Center, Food Processing \\ and Sensory Quality Unit, New Orleans, LA 70124
}

\begin{abstract}
Additional index words. acetate, apple, Malus $\times$ domestica, aroma, cantaloupe, Cucumis melo var. reticulatus, ester, flavor, gas chromatography, honeydew, Cucumis melo var. inodorus, mass spectrometry, melon, minimal processing, solid phase microextraction

Abstract. Examples from various harvest regimes, storage regimes, cultivars and different packaging methods are presented to characterize volatile ester differences after cutting and how changes occur in characteristic flavors throughout the postharvest life of certain cut fruit products. In many fresh-cut cantaloupe cultivars and in honeydew, there was a relative increase in nonacetates and coinciding relative decrease in acetates during storage. A similar and consistent nonacetate:acetate ester ratio was conserved in cantaloupe from eastern and western U.S. regions, as well as different cultivars from the same field. Furthermore, similar ratios were observed in many melon cultivars over multiple years from different seasons and growing regions. Since many cultivars exhibited similar trends in 2-year repeated studies, the trend is apparently independent of year and season. Fresh-cut 'Gala' apples, on the other hand, displayed a slightly different trend whereby both acetates and nonacetate esters decreased appreciably during storage. The hypothesis is put forward that recycling of esters during storage in certain fresh-cut fruits disturbs the delicate fine balance of characteristic volatiles. Consistently decreasing acetates along with increasing nonacetates could alter the overall perceived desirable flavor attributes during fresh-cut melon storage, even though volatile esters are still abundant.
\end{abstract}

Fresh-cut fruit popularity and sales are gaining rapidly across the U.S. Total fresh-cut sales (food service plus retail) was expected to be $\$ 14$ billion in 2003 (Produce Marketing Association, 1999a). Fresh-cut sales have grown in a linear manner, at roughly $\$ 1$ billion per year (Fresh Cut, 1999b), due largely to increased regional production and distribution. In fact, according to recent retail scan data from August 2002-03 (Information Resources Inc.) fresh-cut fruit sales hit \$243 million, an impressive $15 \%$ increase in one year (Western Farm Express, 2003). Melons and fresh-cut melons are rapidly gaining a large share of the produce market (Bareuther, 2000) and therefore a substantial monetary incentive exists to improve their intrinsic qualities.

Fresh-cut processing increases respiration rates and causes major tissue disruption as enzymes and substrates normally sequestered within the vacuole become mixed with other cytoplasmic and nucleic substrates and enzymes. Processing also increases woundinduced ethylene, and surface area per unit volume which may enhance microbial attack and accelerate water loss (Toivonen and DeEll, 2002; Watada and Qi, 1999; Wiley, 1994). These physiological changes may be accompanied by flavor loss, browning, decay, increased rate of vitamin loss, rapid softening, color loss and a shorter storage life. Increased water activity and mixing of intracellular and

\footnotetext{
The author thanks Dean Liere and Alex May, Syngenta Seeds, Inc., Rogers Brand Vegetable Seeds, for supplying cantaloupe; Gene Lester for supplying honeydew; Ken Gross for supplying apples; and Jeanne M. Lea and Debbie Harrell for volatile analysis. The mention of firm names or trade products does not imply that they are endorsed or recommended by the U.S. Department of Agriculture over other similar firms or products not mentioned.

${ }^{1}$ Research plant physiologist, to whom correspondence should be addressed; e-mail beaulieu@srrc. ars.usda.gov.
}

intercellular enzymes and substrates may also contribute to flavor and texture changes and loss during processing and in storage.

Consumer acceptance of fresh-cut fruits often relies on inherent flavor and texture, since they are less likely to be served with accompaniments. It is often assumed that "if it looks good, it tastes good." Compared with salads, the relatively slow expansion of the fresh-cut fruit market may be attributed to the consumer's apprehension to repeatedly purchase products with inconsistent or unsatisfactory flavor or textural quality (Beaulieu and Baldwin, 2002). Consistent postharvest quality of fresh-cut fruits, with flavor, is likely required for a lasting marketability window and sustained consumer acceptance. Yet, there is a detrimental trade-off between firmness/maturity and acceptable volatiles and flavor/aroma attributes in fresh-cut fruits (Beaulieu and Lea, 2003b; Beaulieu et al., 2004; Gorny et al., 1998, 2000). Furthermore, cantaloupe fruit harvested before development of the abscission zone will not develop flavor and aroma volatiles similar to fruit that remained on the vine until fully ripe (Beaulieu, 2006; Pratt, 1971; Wyllie et al., 1996). Yet, fruit harvested at or after development of the abscission zone have a shorter storage life and flavor loss may occur before completion of the marketing process (Hoover, 1955; Ogle and Christopher, 1957).

Research reports illustrating flavor and textural quality in cut fruits are emerging (Beaulieu, 2006; Beaulieu and Baldwin, 2002; Beaulieu and Lea, 2003b; Beaulieu et al., 2004; Bett-Garber et al., 2003; Lamikanra and Richard, 2002; Saftner et al., 2003; Soliva-Fortuny et al., 2002a, 2002b, 2003). However, reports geared toward understanding mechanisms responsible for generation and/or loss of flavor after processing, through the marketing and consumption windows are lacking. An underlying goal in my laboratory is to improve the sensory quality of fresh-cut fruits by obtaining a basic understanding of the physiological and biochemical processes involved in flavor loss and textural change. Subsequently, factors such as harvest maturity, cultivar, inbred parental lineage and season were evaluated with regards to the volatile balance, and flavor changes that occur during storage $\left(4^{\circ} \mathrm{C}\right)$ in the processed product.

\section{MATERIALS AND METHODS}

Plant material, fresh cutting, and sample preparation. Cantaloupe (Cucumis melo L. var. reticulatus, Naudin) culture, harvest, shipment, processing, and solid phase microextraction(SPME) gas chromatography-mass spectrometry (GC-MS) analysis were performed as previously described (Beaulieu, 2006; Beaulieu and Grimm, 2001; Beaulieu and Lea, 2003a; Beaulieu et al., 2003, 2004; Bett-Garber et al., 2003). Briefly, ripe fruit (3/4-slip, peduncle almost abscised) were harvested in California and Arizona (western shippers) or Pennsylvania and Georgia (eastern shippers) according to rigorous standards where maturity at first or second commercial harvest was carefully evaluated, per cultivar (ground color, netting, ${ }^{\circ}$ Brix and taste, firmness and absence of scars, sunburn or surface defects). In the maturity analysis, 'Sol Real' fruit were harvested two years in Calif. according to strict maturity designations where 1/4-slip fruit had a clearly green, well-attached peduncle; 1/2-slip had a distinct abscission zone detectable at the peduncle; 3/4-slip were essentially at or approaching commercial harvest; full-slip (FS) cleanly separated from the vine with light pressure or had just separated; and overripe (OR) were precisely categorized as 2 $\mathrm{d}$ past FS. Regarding fruit utilized for inbred parental analyses, both 'Sol Real' (a typical western shipper) and 'Athena' (an eastern melon) and both homozygous inbred parental breeding lines (designated as male and female 
for proprietary reasons) were harvested at 3/4-slip with uniform size and ground color change and full netting in three seasons from Arizona and California.

Fruit were field hydrocooled in an ice slurry, then cooled on harvest date in a forced air cooler (about $5^{\circ} \mathrm{C}$ ), packed carefully with Styrofoam packaging beads and overnight freighted to the Southern Regional Research Center (SRRC) for analysis within $2 \mathrm{~d}$ after being held at $4^{\circ} \mathrm{C}$. Fruit were washed thoroughly in cold tap water then sanitized via rubbing with gloved hands for roughly $30 \mathrm{~s}$ in $100 \mathrm{ppm}$ bleach $\left(\mathrm{NaClO}, \mathrm{pH}\right.$ about $\left.6.5,4{ }^{\circ} \mathrm{C}\right)$, rinsed in deionized water and uniformly peeled on a melon peeler (CP-44; Muro, Tokyo, Japan). Stem and blossom portions (about 2 to $3 \mathrm{~cm}$ ) were removed, and roughly $2.5-\mathrm{cm}^{3}$ mesocarp cubes were prepared from many fruits ( 5 to 6 minimum) per treatment. Cubes were randomized per $300 \mathrm{~g}$ triplicate in 24-ounce (about1 L) low-profile, ridged-bottom, Juice Catcher containers (SRW-24-JC; Winkler Forming Inc., Carrollton, Texas). Containers were stored at $4{ }^{\circ} \mathrm{C}$ and fresh-cut cubes were assessed after various days in storage.

'Honey Brew' honeydew (Cucumis melo L. var. inodorus, Naudin) plants were grown in Weslaco, Texas, and field treated with various foliar calcium compounds $(6 \%$ mineral $\mathrm{Ca})$ including amino acid chelated-calcium (Met- alosate, Albion Laboratories Inc., Clearfield, Utah), calcium chloride, and Ca-EDTA chelated-calcium plus water controls, at the rate of $2.3 \mathrm{~L} \cdot \mathrm{ha}^{-1}$ at $0,1,2$, or 4 total applications during growth similar to Lester and Grusak (2004).Applications were at female flowering, within 20 and $40 \mathrm{~d}$ after flowering, and within 3 to $5 \mathrm{~d}$ before harvest. Harvested fruit were handled and processed, as described above. A Katz 100 (Koch Equipment, LLC, Kansas City, Mo.) modified atmosphere packaging (MAP) machine was used to produce passive packages in polypropylene 5002 trays (GreenTek, Inc.) overwrapped with 2.5-mil-thick (63.5- $\mu \mathrm{m})$ ESEVE 1250R film (Winpak Ltd., Minneapolis, Minn.).

'Gala' apples (Malus $\times$ domestica Borkh.) were harvested in Pennsylvania and 18.2-kg boxes were shipped overnight delivery to the SRRC. Unblemished apples (about $250 \mathrm{~g}$ each) were washed and sanitized in $100 \mathrm{ppm}$ hypochlorite solution ( $\mathrm{pH}$ adjusted to 6.5 to 7.0 with citric acid) at $10{ }^{\circ} \mathrm{C}$, and rinsed under cold tap water. Tops (peduncle) and bottoms (calyx, stamen and pistil remnants) of 24 fruit, per treatment, were sliced off with a knife, cut into 10 wedges with a stainless steel corer-wedger, and further trimmed (about 3 $\mathrm{mm}$ ) to remove cartilaginous endocarp tissue. Wedges were submerged in a holding solution of $0.25 \% \mathrm{NaCl}(\mathrm{w} / \mathrm{v})$ to prevent browning until sufficient tissue was ready for blocking and browning inhibitors (BI). Wedges were submerged in $2 \%(\mathrm{v} / \mathrm{v})$ sodium erythorbate plus $0.1 \%(\mathrm{w} / \mathrm{v})$ calcium chloride (Sapers and Miller, 1998) with gentle agitation for $1 \mathrm{~min}$ at $10{ }^{\circ} \mathrm{C}$. Wedges were spun 15 to $20 \mathrm{rpm}$ for $10 \mathrm{~s}$ in a salad spinner, blotted dry and $85 \mathrm{~g}$ sealed in 2.6 mils thickness $(66.0 \mu \mathrm{m})$ low density polyethylene (LDPE, 640B; Cryovac, Duncan, S.C. $)$ bags $\left[393.7 \mathrm{~cm}^{3} \cdot \mu \mathrm{m}\left(\mathrm{m}^{2} \cdot \mathrm{d} \cdot \mathrm{atm}\right)^{-1}\right.$ OTR], with triplicates evaluated after $0,2,7$, and $14 \mathrm{~d}$ storage at $4{ }^{\circ} \mathrm{C}$.

\section{Volatile preparation: SPME GC and GC-MS analysis}

Manual SPME: Melons. Triplicate volatile samples were prepared from a representative pool ( 8 to 10 cubes) of tissue from storage containers. Tissue was juiced (about $15 \mathrm{~s}$ ) into slurries with a Braun MP80 Juicer (Gillette Company, Boston, Mass.), $7 \mathrm{~mL}$ was pipetted into $12-\mathrm{mL}$ glass vials containing $2.5 \mathrm{~g} \mathrm{NaCl}$ and a magnetic stir bar. Vials were sealed with a steel crimp cap fitted with a black viton lid, stirred for $12.5 \mathrm{~min}$ at $40{ }^{\circ} \mathrm{C}$ in a water bath while exposed to a $100 \mu \mathrm{m}, 1 \mathrm{~cm}$ PDMS manual SPME fiber (Supelo, Bellefonte, Pa.). Before use, vials, lids, septa, stir bars and $\mathrm{NaCl}$ were baked overnight at $190^{\circ} \mathrm{C}$. SPME fibers were initially conditioned each day by baking them out for $1 \mathrm{~h}$ in the GC inlet, held at 250

Table 1. Characteristic impact flavor and aroma compounds (CIFAC) ${ }^{\mathrm{z}}$ reported in Cucumis melo, and their associated aroma-flavor sensory attributes.

\begin{tabular}{|c|c|c|c|}
\hline $\begin{array}{l}\text { Compound class } \\
\text { and compound }\end{array}$ & $\mathrm{RI}^{\mathrm{y}}$ & $\mathrm{CAS}^{\mathrm{x}}$ no. & Sensory attributes ${ }^{\mathrm{w}}$ \\
\hline \multicolumn{4}{|l|}{ Acetates } \\
\hline 3-Methylbutyl acetate & 876 & $123-92-2$ & Banana, fragrant, fruity, sweet \\
\hline 2-Methylbutyl acetate & 877 & $624-41-9$ & Banana, candy, citrus, ether, floral, fresh, fruity, peanuts, vegetable \\
\hline Hexyl acetate & 1011 & $142-92-7$ & Apple, cherry, floral, pear, pine \\
\hline (E)-3-hexenyl acetate & 1018 & $33467-73-1$ & Green, sweet, vegetable, waxy \\
\hline (Z) 6-nonenyl acetate & $\mathrm{NR}^{\mathrm{v}}$ & & \\
\hline$(Z, Z)$ 3,6-nonadienyl acetate & NR & & \\
\hline Benzyl acetate & 1164 & $140-11-4$ & Floral, fresh, fruity, pine, sweet \\
\hline \multicolumn{4}{|l|}{ Nonacetate esters } \\
\hline Ethyl 2-methylpropanoate & 751 & $97-62-1$ & Citrus, floral, melon-like \\
\hline Methyl 2-methylbutanoate & 772 & $868-57-5$ & Apple, artificial strawberry, floral, fruity, medicinal, sweet \\
\hline Ethyl butanoate & 803 & $105-54-4$ & Banana-pineapple, candy, fragrant, fruity, ethereal, medicinal, sweet, sick \\
\hline Ethyl 2-methylbutanoate & 846 & $7452-79-1$ & Cantaloupe-like, floral, fruity, green, powerful, pungent, strawberry, sweet \\
\hline Ethyl hexanoate & 999 & $123-66-0$ & Apple, banana, brandy, floral, fruity, powerful, wine-like \\
\hline \multicolumn{4}{|l|}{ Alcohols } \\
\hline Eucalyptol & 1032 & $470-82-6$ & Camphoraceous \\
\hline (Z)-6-nonenol & 1171 & $35854-86-5$ & Green, melon, powerful, sweet \\
\hline (Z, Z)-3,6-nonadienol & NR & $53046-97-2$ & Boiled leaf-like, grassy \\
\hline \multicolumn{4}{|l|}{ Aldehydes } \\
\hline (E)-2-hexenal & 850 & $6728-26-3$ & Apple, fragrant, fruity, green, leafy, plum, sweet, vegetable \\
\hline (Z)-3-hexenal & NR & $6789-80-6$ & Green, leafy, powerful, strawberry leaf, winey \\
\hline (Z)-6-nonenal & 1101 & $2277-19-2$ & Citrus, melon \\
\hline$(E, Z)-2,6$-nonadienal & 1155 & $557-48-2$ & Cucumber, green, violet, waxy \\
\hline (E)-2-nonenal & 1162 & $18829-56-6$ & Fatty, penetrating, waxy \\
\hline \multicolumn{4}{|l|}{ Sulfur-compounds and others } \\
\hline S-methyl thiobutanoate & NR & $2432-51-1$ & Cabbage, cheese, garlic, pine/earthy, pungent, putrid, rancid, sour \\
\hline 3-(Methylthio)propanal & NR & $3268-49-3$ & Earthy, meaty, musty, onion, potato, stale, sulfury, tomato \\
\hline Ethyl 2-(methylthio)acetate & 981 & $4455-13-4$ & Cucumber-like \\
\hline Ethyl 3-(methylthio)propanoate & 1098 & $13327-56-5$ & Caramelized pineapple, fresh, fruity, green, melon, metallic, stale, sulfury \\
\hline 3-(Methylthio)propyl acetate & 1123 & --- & Apples \\
\hline (Z)-1,5-octadien-3-one & NR & $65767-22-8$ & --- \\
\hline
\end{tabular}

${ }^{2}$ CIFAC status based on (Buttery et al., 1982; Horvat and Senter, 1987; Kemp et al., 1972; Nussbaumer and Hostettler, 1996; Schieberle et al., 1990; Wyllie and Leach, 1992; Wyllie et al., 1994, 1995).

${ }^{\mathrm{y}} \mathrm{RI}=$ retention index on a DB-5 column (crosslinked 5\% phenyl methyl silicone) based on a combination of retention times compared to standards and calculated Kovats Indices for both GC-MS (Beaulieu and Grimm, 2001) and GC-FID.

${ }^{\mathrm{x}} \mathrm{CAS}=$ Chemical Abstract Service.

wSensory attributes based on above references (Hayata et al., 2003; Jordán et al., 2001) and FlavorWorks (v 2.0) (Flavometrics, Anaheim Hills, Calif.).

${ }^{\mathrm{N} R}=$ not recovered. Certain CIFAC appear within the literature sparingly either due to cultivar (i.e., across different flesh- and rind-types within $\mathrm{Cucumis)}$ and/or due to method limits/differences. 
${ }^{\circ} \mathrm{C}$. Fibers were desorbed in a GC (HP5890; Agilent Technologies, Wilmington, Del.) equipped with a $60 \mathrm{~m}$ DB-5 (crosslinked 5\% phenyl methyl silicone), $0.25 \mathrm{~mm}$ ID, 0.25 $\mu \mathrm{m}$ column (J\&W Scientific, Folsom, Calif.) and a FID detector. Samples were run with the following conditions: initial temperature $50{ }^{\circ} \mathrm{C}$ for $1 \mathrm{~min}$, purge off, purge on at $1 \mathrm{~min}$ and off again at $20 \mathrm{~min}$, ramped at $5^{\circ} \mathrm{C} \cdot \mathrm{min}^{-1}$ until 100 ${ }^{\circ} \mathrm{C}$, then ramped $15^{\circ} \mathrm{C} / \mathrm{min}$ until $250{ }^{\circ} \mathrm{C}$ and held 19 min with the injector port at $250{ }^{\circ} \mathrm{C}$ and the detector at $280{ }^{\circ} \mathrm{C}$. The injection port was operated in splitless mode and subjected to a pressure of $172 \mathrm{kPa}$ of ultra high purity He $(99.9995 \%)$ for the first minute, and then set at a constant velocity of $32.4 \mathrm{~cm} \cdot \mathrm{s}^{-1}$ for the remainder of the GC run. Twenty-seven compounds eluting within the first $18 \mathrm{~min}$. were identified and verified by comparison with standards. Compounds were also confirmed by comparison of RTs to identical replicate slurries with manual SPME fibers that were run on GC-MS, with similar conditions as described below.

Manual SPME: Apples. The contents of each $85-\mathrm{g}$ bag were placed into a $500-\mathrm{mL}$ I-

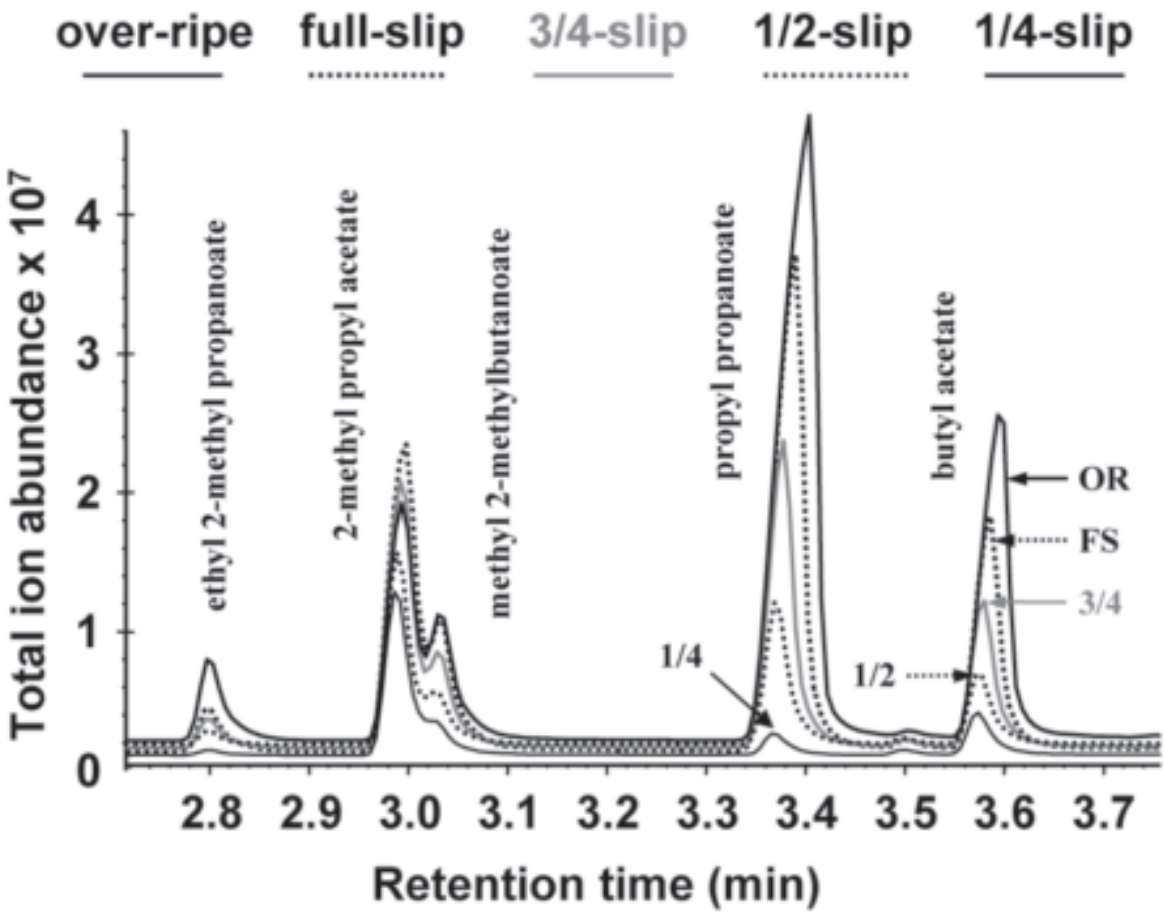

Fig. 1. Total ion chromatograms of 'Sol Real' cantaloupe fruit harvested at 5 discrete maturities sampled by solid phase microextraction (SPME) gas chromatograph-mass spectrometry (GC-MS). Representative ion traces per maturity are off-set 250,000 counts.

\section{Branched chain amino acids}

amino transferases

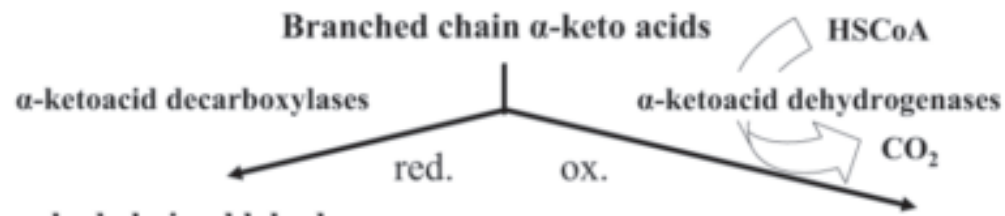

Branched chain aldehydes

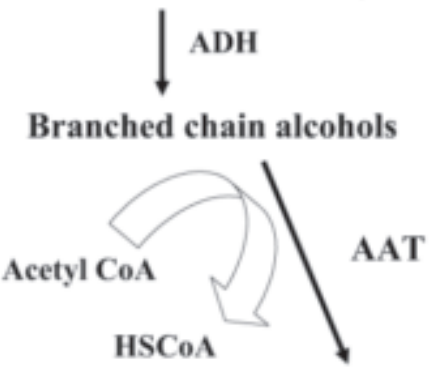

\section{Branched chain acetates}

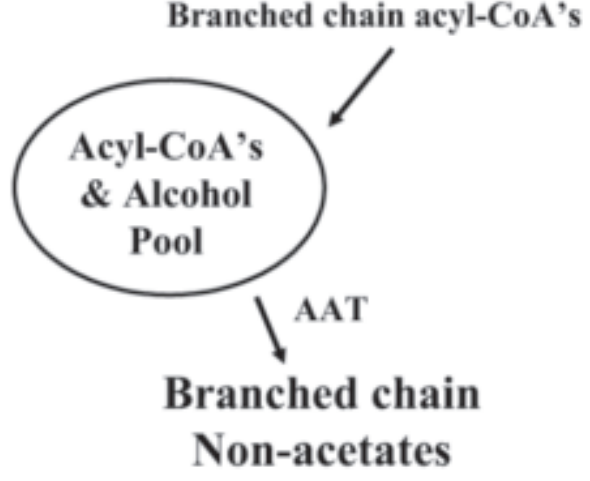

Fig. 2. General biosynthetic pathway for branched chain acetate and nonacetate esters derived from amino acids. Schematic adapted from (Bauchot et al., 1998).

Chem jar, sealed with a septa lid, placed in a water bath at $40{ }^{\circ} \mathrm{C}$. A PDMS $(100 \mu \mathrm{m}, 1 \mathrm{~cm})$ SPME fiber was inserted to capture headspace volatiles during a $15 \mathrm{~min}$ static exposure. Desorption and remaining GC-MS conditions were identical to those below, except 29 compounds were identified and verified by comparison with standards and the library.

Automated SPME: Melons. GC-MS analysis were performed as previously described (Beaulieu, 2006; Beaulieu and Grimm, 2001). Briefly, random samples per treatment were used to prepare 3-mL juice (Braun MP80 Juicer) that were pipetted into $10-\mathrm{mL}$ glass vials containing $1.1 \mathrm{~g} \mathrm{NaCl}$. Then 2-methylbutyl3-methylbutanoate internal standard (IS) was added, sealed with a steel crimp cap fitted with a Teflon/silicon septum, and placed on a Combi-Pal Autosampler (Leap Technologies, Carrboro, N.C.) cooling rack at $4{ }^{\circ} \mathrm{C}$. Vials were equilibrated $10 \mathrm{~min}$ via oscillation in a $40{ }^{\circ} \mathrm{C}$ autosampler, then a $1-\mathrm{cm} 100 \mu \mathrm{m}$ polydimethylsiloxane (PDMS) SPME fiber was inserted into the headspace for $12.5 \mathrm{~min}$, agitated at $100 \mathrm{rpm}$, at $40{ }^{\circ} \mathrm{C}$.

Fibers were desorbed at $250^{\circ} \mathrm{C}$ for $1 \mathrm{~min}$ in the injection port of an HP6890/5973 GC-MS (Agilent Technologies, Wilmington, Delaware) with a DB-5 column ( $30 \mathrm{~m}, 0.25 \mathrm{~mm}$ i.d., 25 $\mu \mathrm{m}$ film thickness) for 30 to $35 \mathrm{~min}$ runs. The injection port was operated in splitless mode and subjected to a pressure of $172 \mathrm{kPa}$ of ultrahigh purity helium (99.9995\%) for the first minute, then flow velocity was constant at 40 $\mathrm{cm} \cdot \mathrm{s}^{-1}$ for the remainder of the GC run. The initial oven temperature was $50^{\circ} \mathrm{C}$, held $1 \mathrm{~min}$, ramped 5 to $100{ }^{\circ} \mathrm{C}$ then $10{ }^{\circ} \mathrm{C} \cdot \mathrm{min}^{-1}$ to 250 ${ }^{\circ} \mathrm{C}$ and held $9 \mathrm{~min}$. The HP5973 quadrupole mass spectrometer was operated in the electron ionization mode at $70 \mathrm{eV}$ (electron volts), a source temperature of $200^{\circ} \mathrm{C}$, with a continuous scan from $\mathrm{m} / \mathrm{z}$ (mass to charge ratio) 33 to 300. Data were collected with HPChemStation software (A.03.00) and searched against the NIST v. 1.5 and Wiley v. 7 NIST98 (Palisade Corp., Newfield, N.Y.) or Wiley7th/NIST02 registry of mass spectral data libraries (McLafferty, 2000). Selected compounds (e.g., Table 1) were confirmed by their library matches, standards and comparison to an in-house library and retention index (RI) (Beaulieu, 2006; Beaulieu and Grimm, 2001).

Data analysis. Results were calculated per compound or compound classes as the integrated target response ( $\mathrm{GC}-\mathrm{MS}$ ) or area (GC-FID) divided by the total target response or area, respectively, of the suite of compounds positively identified per experiment or cultivar (denoted in figure legends). Data were subsequently expressed as relative percentages (relative abundance in apple) of averaged target ion response or area of specified compounds or compound classes, in triplicate $(\mathrm{n}=3)$, generally combined over 2 years.

\section{RESULTS AND DISCUSSION}

Nineteen compounds have been considered characteristic impact flavor or aroma compounds (CIFAC) in ripe Cucumis melo (Buttery et al., 1982; Horvat and Senter, 1987; 

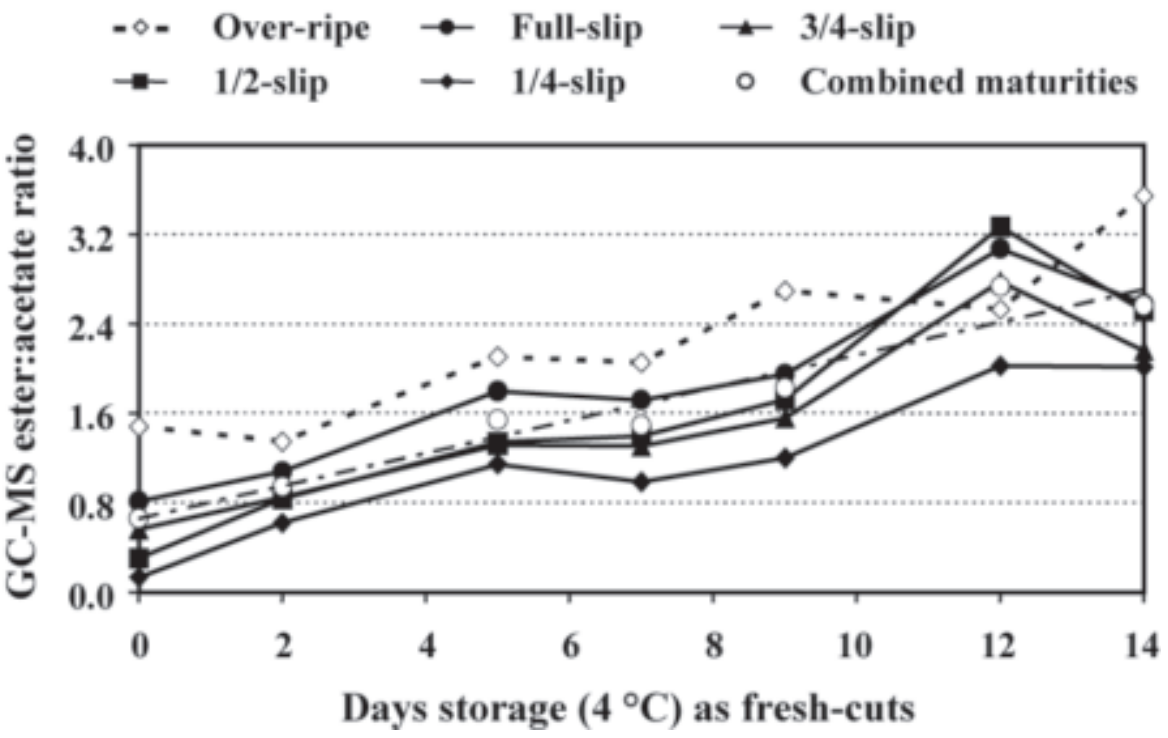

Fig. 3. SPME GC-MS nonacetate ester to acetate ratios (nonacetate/acetate) in fresh-cut 'Sol Real' cantaloupe prepared from five distinct maturities (1/4-, 1/2-, 3/4-, FS, and OR), stored at $4{ }^{\circ} \mathrm{C}$. Linear equation represents five combined maturities. Calculations based on the composite averages of $n=6$ runs repeated over 2 years for each maturity, except OR and day 12 and $14(n=3)$, where 11 of the 58 integrated compounds were acetates, and 17 were nonacetate esters.

Kemp et al., 1972; Nussbaumer and Hostettler, 1996; Schieberle et al., 1990; Wyllie et

compounds are believed to be important to al., 1994, 1995), and five additional sulfur

flavor (Horvat and Senter, 1987; Wyllie and Leach, 1992; Wyllie et al., 1994) (Table 1).
The predominant esters considered impact flavor and aroma compounds in C. melo were recently categorized into two classes based on the compound structure (Beaulieu, 2006). Acetates have an acetate ion (acyl group) as the terminal $\mathrm{R}_{\text {acid }}$ attached at the carboxylic group via an ester bond, whereas compounds not containing a methyl group at their $\mathrm{R}$ ' terminus were designated as nonacetate esters.

Cantaloupe. There is a conserved linear increase in most cantaloupe volatile compounds as harvest maturity increases, provided the fruit has not become overripe (Beaulieu, 2006). This relationship is illustrated with typical MS ion traces for esters in cantaloupe harvested at 5 discrete maturities (Fig. 1). Volatile esters, that are important contributors to the aroma of many fruits, are formed by esterification of alcohols, normally utilizing a CoA moiety or CoA-ester as the acyl donor (Harada et al., 1985; Pérez et al., 1996; Shalit et al., 2001; Ueda et al., 1997). Alcohol acetyltransferase (AAT) has been found to be the putative enzyme for aroma volatile ester compounds in many ripening fruits, and melons (Aggelis et al., 1997; Ueda et al., 1997; Yahyaoui et al., 2002).

The concentration of free amino acids increases with $C$. melo fruit ripening (Wyllie et al., 1995, 1996), and amino acids are the putative precursors to many flavor esters and

Table 2. Change in relative percentage of selected acetate and nonacetate esters during storage $\left(4^{\circ} \mathrm{C}\right)$ of fresh-cut 'Sol Real' cantaloupe prepared at five distinct maturities. $^{2}$

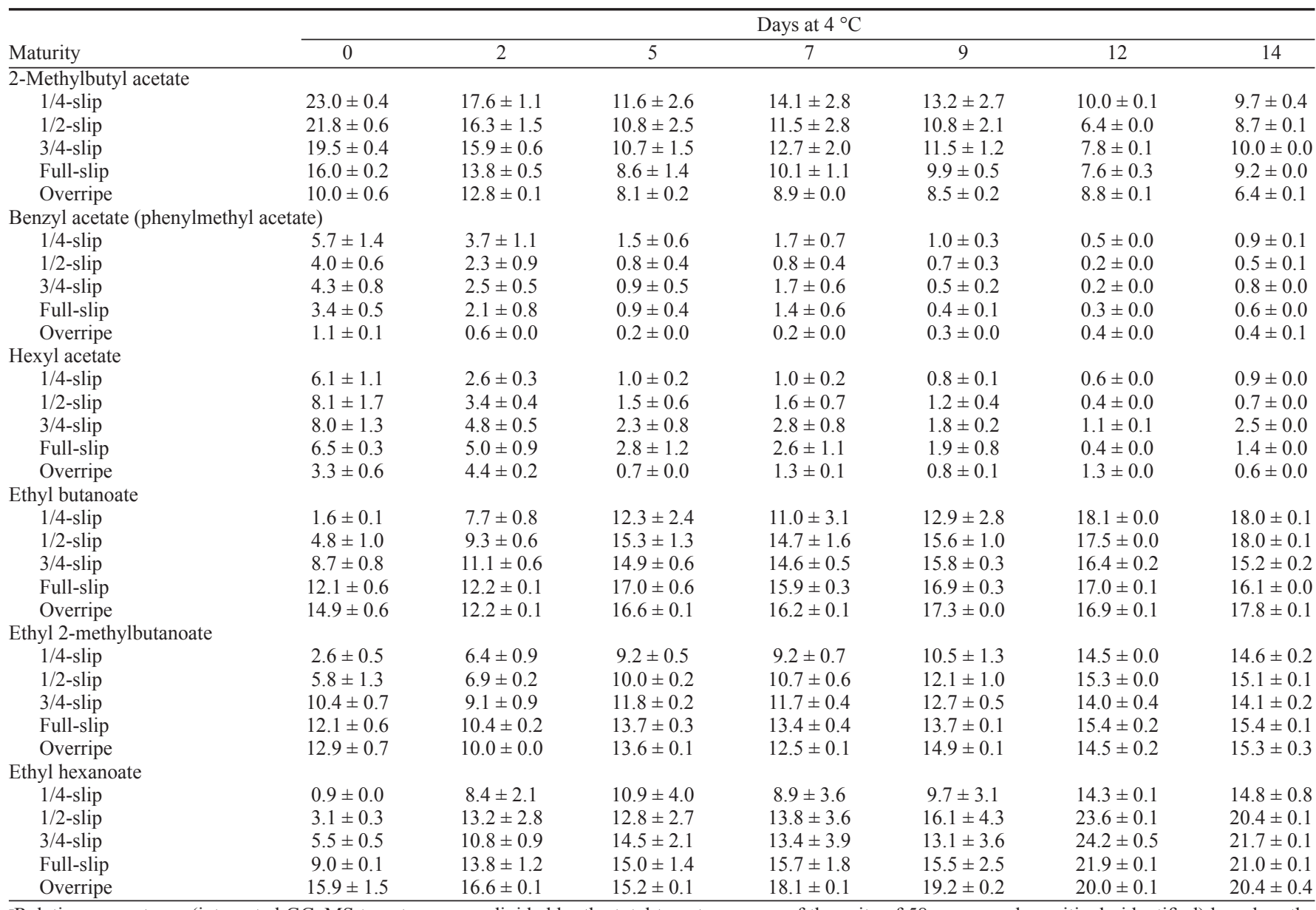

${ }^{2}$ Relative percentages (integrated GC-MS target response divided by the total target response of the suite of 58 compounds positively identified) based on the composite averages of $n=6$ runs taken over 2 years (except days 12 and 14 were from a single year, hence $n=3)$ for each maturity, except OR $(n=3)$, where 11 of the 58 integrated compounds were acetates, and 17 were nonacetate esters, \pm standard deviation. 
Table 3. Changes in the relative percentage in the predominant ester compound classes ${ }^{2}$ during storage $\left(4{ }^{\circ} \mathrm{C}\right)$ of fresh-cut cantaloupe cultivars and their inbred parental lines harvested in 2 years. 'Athena' is an eastern melon whereas 'Sol Real' is a western shipper.

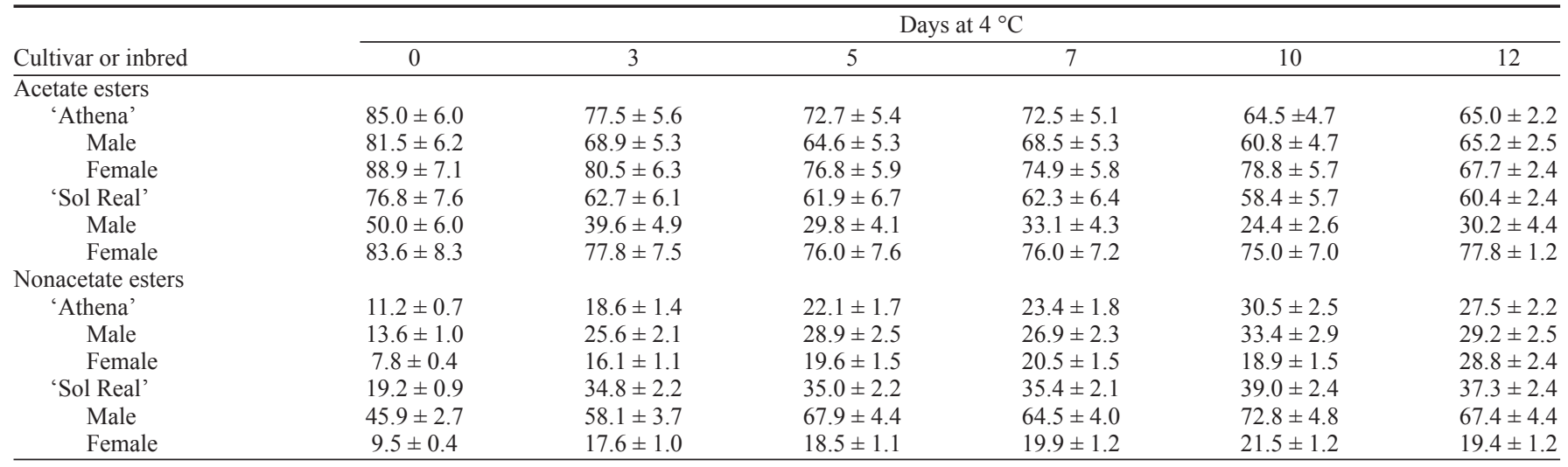

${ }^{2}$ Relative percentages (integrated GC-MS target response divided by the total target response of the suite of 65 compounds positively identified) based on the composite averages of $n=6$ runs taken over 2 years for each cultivar where 18 of the 65 integrated compounds were acetates, and 23 were nonacetate esters, \pm standard deviation.

thioesters (Yabumoto et al., 1977). The AAT enzyme system is responsible for formation of acetates and nonacetate esters, especially aromatic compounds derived from amino acids (Fig. 2). The presented schematic also applies for straight chain esters. When a direct acetylCoA pool is available, acetates may be formed via esterification with many possible alcohols. Alternatively, AAT will esterify other acyl donors such as propionyl-CoA, isovaleryl-CoA, butyryl-CoA, isobutyryl-CoA, hexanoyl-CoA, and benzoyl-CoA, with available alcohols to form nonacetate esters. However, ester types formed in apple and strawberry (Fragaria ananassa) depend on the available substrate pool (Fellman et al., 2000; Pérez et al., 1993; Rowan et al., 1996), and in vivo acyl donor availability in Charentais melon is limiting (Yahyaoui et al., 2002).

The relative proportion of acetates and non acetates was recently reported in cantaloupe across harvest maturity (Beaulieu, 2006), and is elaborated upon in Fig. 3. The data indicate clearly that there is a continuous change in the ester balance (increasing ratio of esters to nonacetate esters) during fresh-cut storage, which is independent of processing maturity. Albeit over-ripe (OR) when processed, the nonacetate to acetate ratio was slightly shifted, but the trend was conserved and indicated a linear $\left(\mathrm{y}=0.146 \mathrm{x}+0.657 ; R^{2}=0.942\right)$ ratio change across all maturities during storage. The relative percentage of flavor-important acetates such as 2-methylbutyl acetate, benzyl acetate and hexyl acetate (Table 2), as well as other abundant acetates like 2-methylpropyl acetate, ethyl 2-phenylacetate and 2-phenylethyl acetate (data not shown) decreased markedly during storage. Similar results have been reported regarding acetate decline in various cantaloupe cultivars (Beaulieu, 2005) and OR and senescing melon fruit (Horvat and Senter, 1987; Yabumoto et al., 1978). Acetates are often considered the most important flavor-related volatiles in many fruits, and were the dominant ester type in many melon cultivars (Table 3, Figs. 4 and 5), honeydew (Buttery et al., 1982) (Fig. 6) and Charentais melons (Bauchot et al., 1998). As previous data illustrated (Horvat and Senter, 1987), acetate esters increased with the ripening of cantaloupe fruit, then decreased as the fruit progress to the OR stage (Beaulieu, 2006), and during fresh-cut storage (Beaulieu,

2005). However, since both total acetate and total ion abundances increased substantially with maturity (Beaulieu, 2006), the calculated

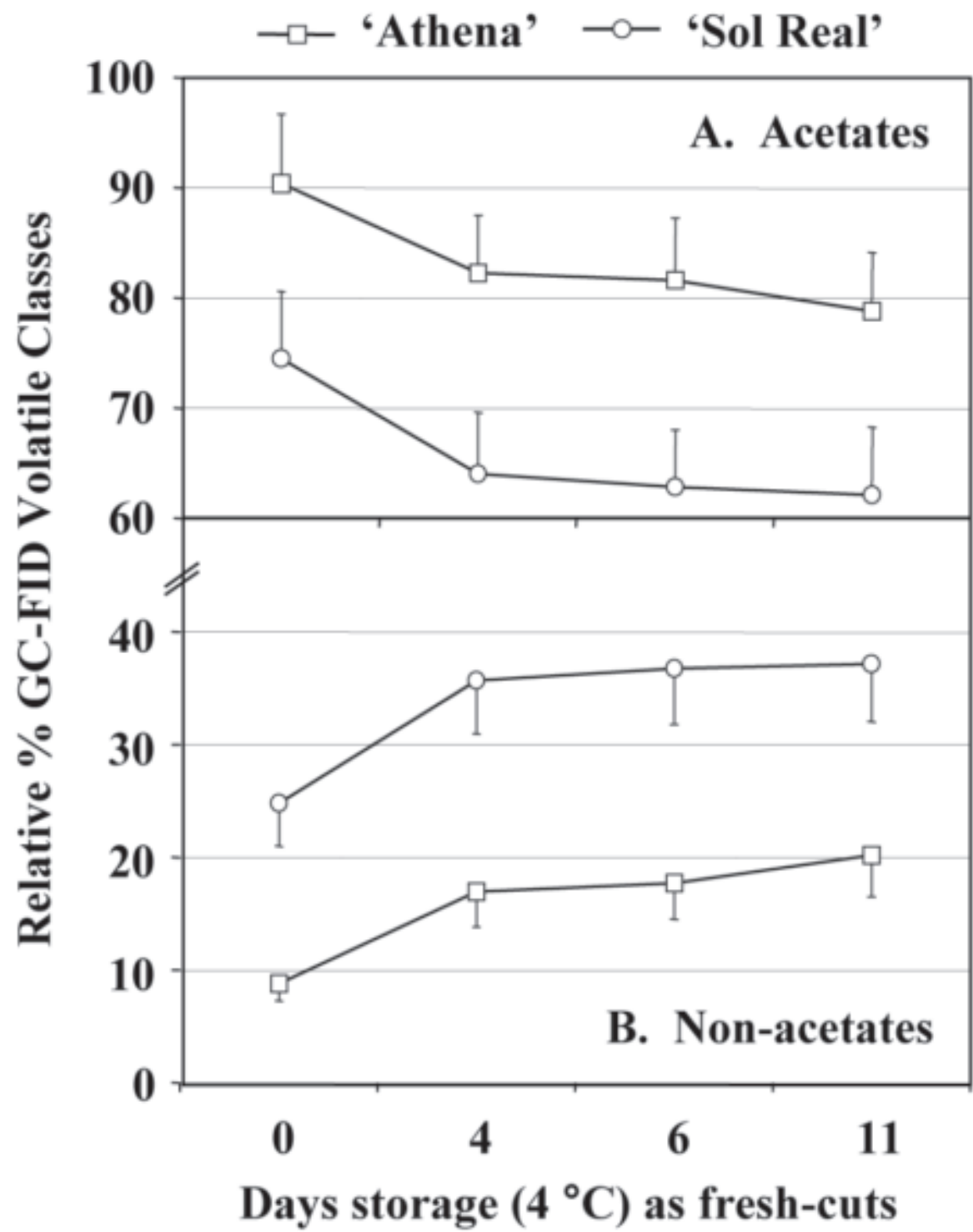

Fig. 4. Relative SPME GC-FID percentage of acetate(A) and nonacetate(B) esters in typical eastern ('Athena') and western ('Sol Real') fresh-cut cantaloupe cubes, stored at $4{ }^{\circ} \mathrm{C}$. Percentages based on 26 integrated compounds, with 15 acetates and 11 nonacetates ( $\mathrm{n}=2$ or 3 per point \pm standard deviation). 
Fig. 5. Relative SPME GC-MS percentage of acetate (A) and nonacetate (B) esters in fresh-cut cantaloupe cubes prepared from typical western cultivars ('Pac Start', 'Primo' and 'Sol Real') from the same field, and an eastern cultivar ('Athena'), stored at $4{ }^{\circ} \mathrm{C}$. Relative percentages ( $\mathrm{n}=6, \pm$ standard deviation) based on selected ion monitoring of 61 integrated compounds, with 11 acetates and 22 nonacetates, repeated over 2 years.

percentages reflect that the relative proportion of most acetate volatiles decreased substantially with increasing harvest maturity (Table 2 ). Reduction of the relative proportion of acetates likely moderates desirable flavors (Table 1 ), and this could be why OR and senescing fruit are generally less accepted compared with fruit at the optimum commercial harvest (e.g., 3/4-slip). With increased harvest maturity, the relative recovery of ethyl butanoate, ethyl 2methylbutanoate, ethyl hexanoate (Table 2), ethyl propanoate, ethyl 2-methylpropanoate, methyl 2-methylbutanoate and methyl hexanoate (data not shown) increased markedly during fresh-cut storage. Although many of these compounds have desirable melon attributes, substantial relative increases in some of these compounds could produce undesirable flavor attributes (Table 1). Consequentially, OR fruit are generally not preferred compared with 3/4-slip or FS. Most of these esters utilize ethanol as their synthetic substrate. Alcohols generally increase during fruit senescence, and catabolism of acetate esters could furnish the acyl portion of these esters, facilitating increased production during storage (Fig. 2). However, methyl and ethyl acetate were not reliably recovered in the maturity study reported herein. Nonetheless, there was a significant maturity-dependent linear increase in 11 other acetates where $1 / 4$-slip $<1 / 2$-slip $<3 / 4$-slip < FS (Beaulieu, 2006).

In many melon cultivars, there is a relative increase in nonacetates, at the expense of the relative decrease in acetates during fresh-cut storage (Table 3, Figs. 4-6; Beaulieu, 2005). The melon literature clearly indicates that substantial differences exist in volatile profiles of different $C$. melo types and cultivars, and substantial differences were noted herein (Fig. 5) and also within inbreds of two cultivars harvested in 2 years (Table 3). Many European, Israeli and Charentais melons are considered to be more aromatic than standard cantaloupe cultivars grown in the western U.S. Seed companies often breed a female line to morphologically resemble the commercial hybrid and place many "specialty" or

Fig. 6. Relative SPME GC-MS percentage of (A) acetate (15 of 38 compounds) and (B) nonacetate esters ( 8 of 38 compounds) in fresh-cut 'Honey Brew' cubes prepared from plants sprayed with different calcium compounds, according to the materials and Methods. Foliar calcium compounds $(6 \% \mathrm{Ca})$ were amino acid chelated-calcium (Amino-Ca), calcium chloride $\left(\mathrm{CaCl}_{2}\right)$, and EDTAchelated calcium (EDTA-Ca) plus water controls. An additional passively modified atmosphere package was produced with control-sprayed fruit. Averages are triplicates \pm standard deviation.

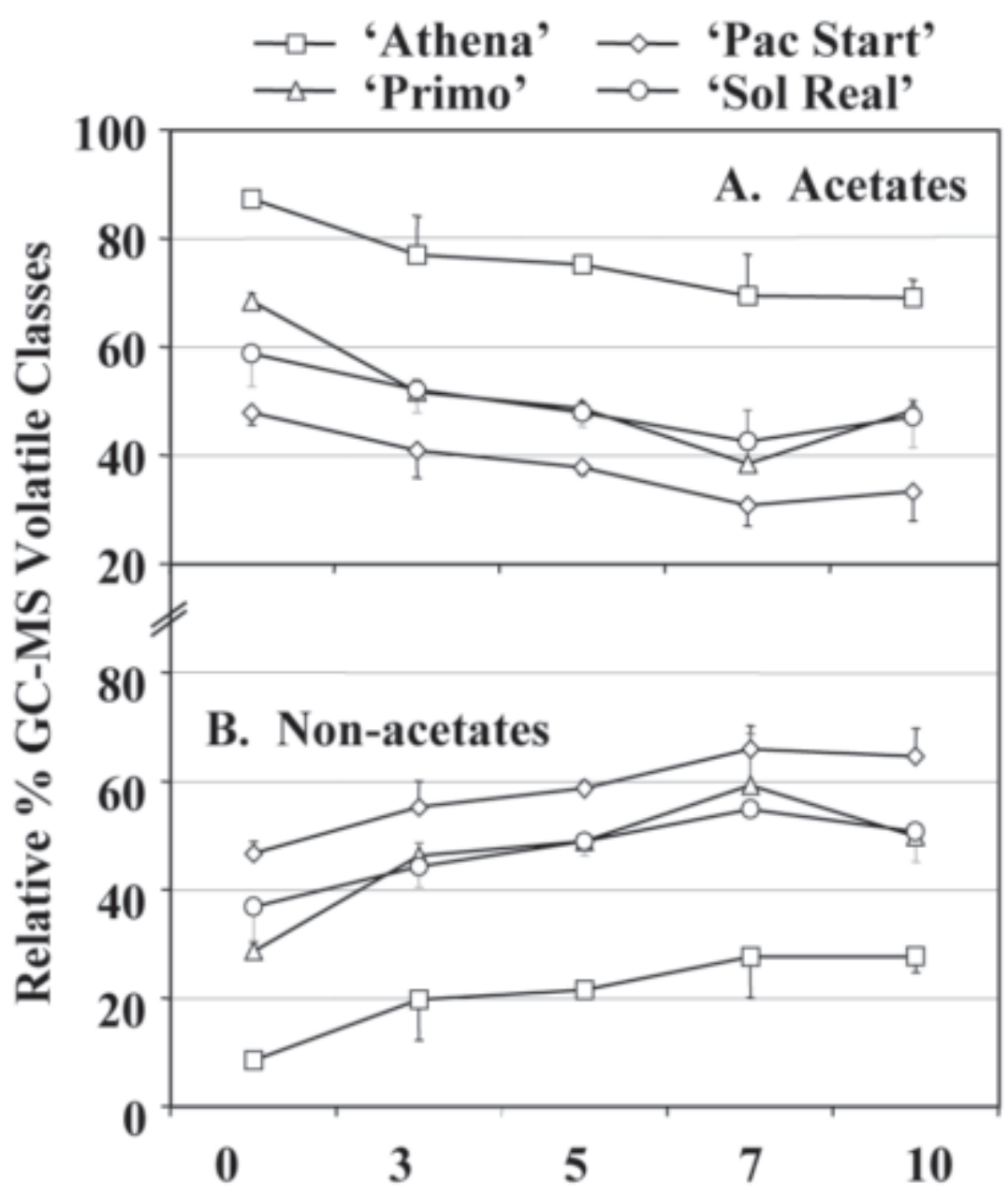

Days storage $\left(4^{\circ} \mathrm{C}\right)$ as fresh-cuts
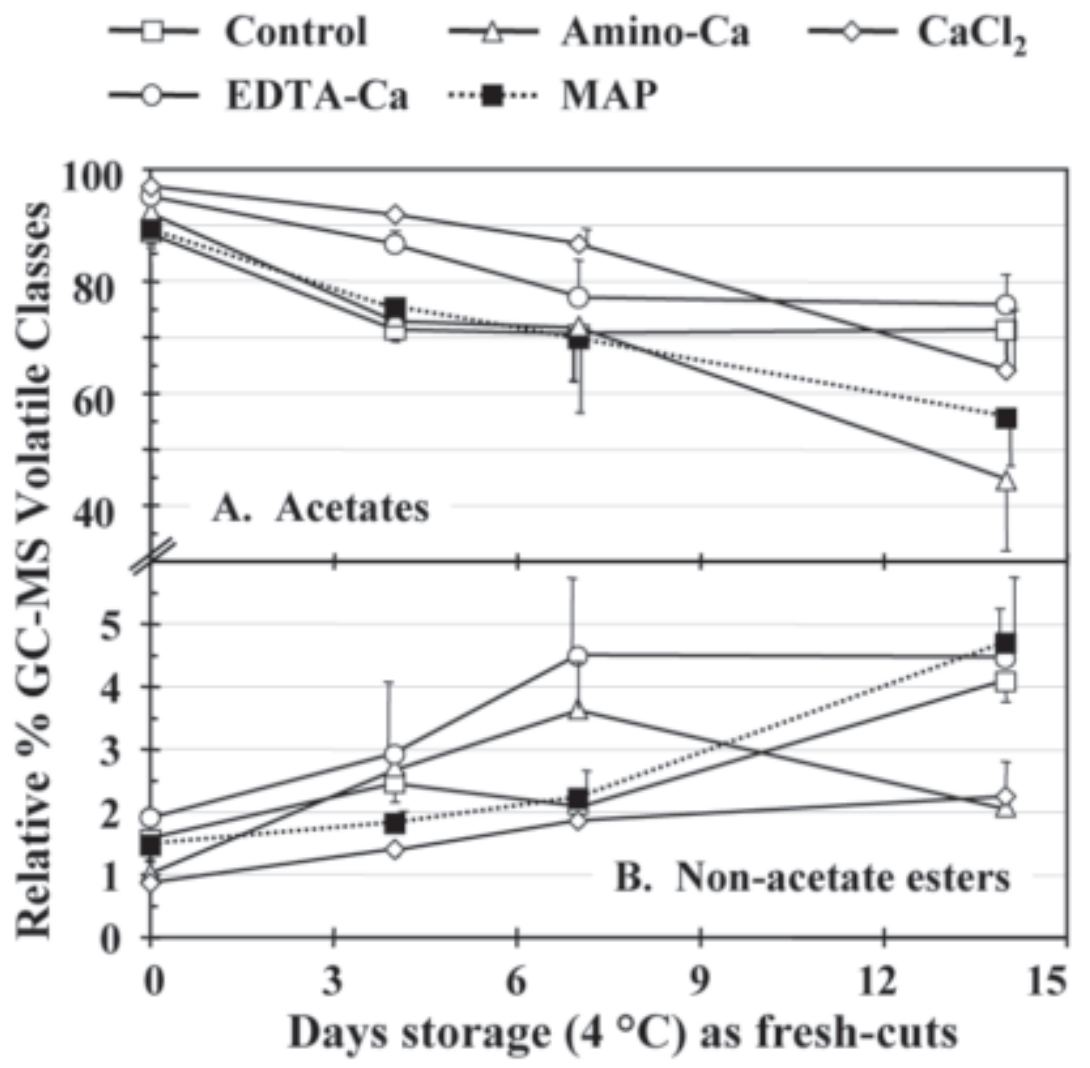
"unique" horticultural traits in the male inbred to avoid losing proprietary secrets (Beaulieu et al., 2003). The 'Athena' male does not have a traditional western shipper genetic background, and has much higher acetates and lower nonacetates compared with the 'Sol Real' male inbred. With the exception of the 'Sol Real' male, acetates constituted $>75 \%$ of the total volatiles upon cutting, yet this proportion declined by roughly $16.6 \%$ after
$12 \mathrm{~d}$ storage (Table 3 ). This may explain why the 'Sol Real' hybrid is less aromatic and has lower acetate levels than 'Athena'.

The acetate and nonacetate relationship was also conserved in eastern and western shipper melons (Fig. 4), cultivars ('Gold Rush', 'Mission', 'Oro Rico', 'Sol Dorado' and 'Sol Real') from the same field in one year (Beaulieu, 2005), as well as cultivars ('Athena', 'Pac Start', 'Primo' and 'Sol Real')

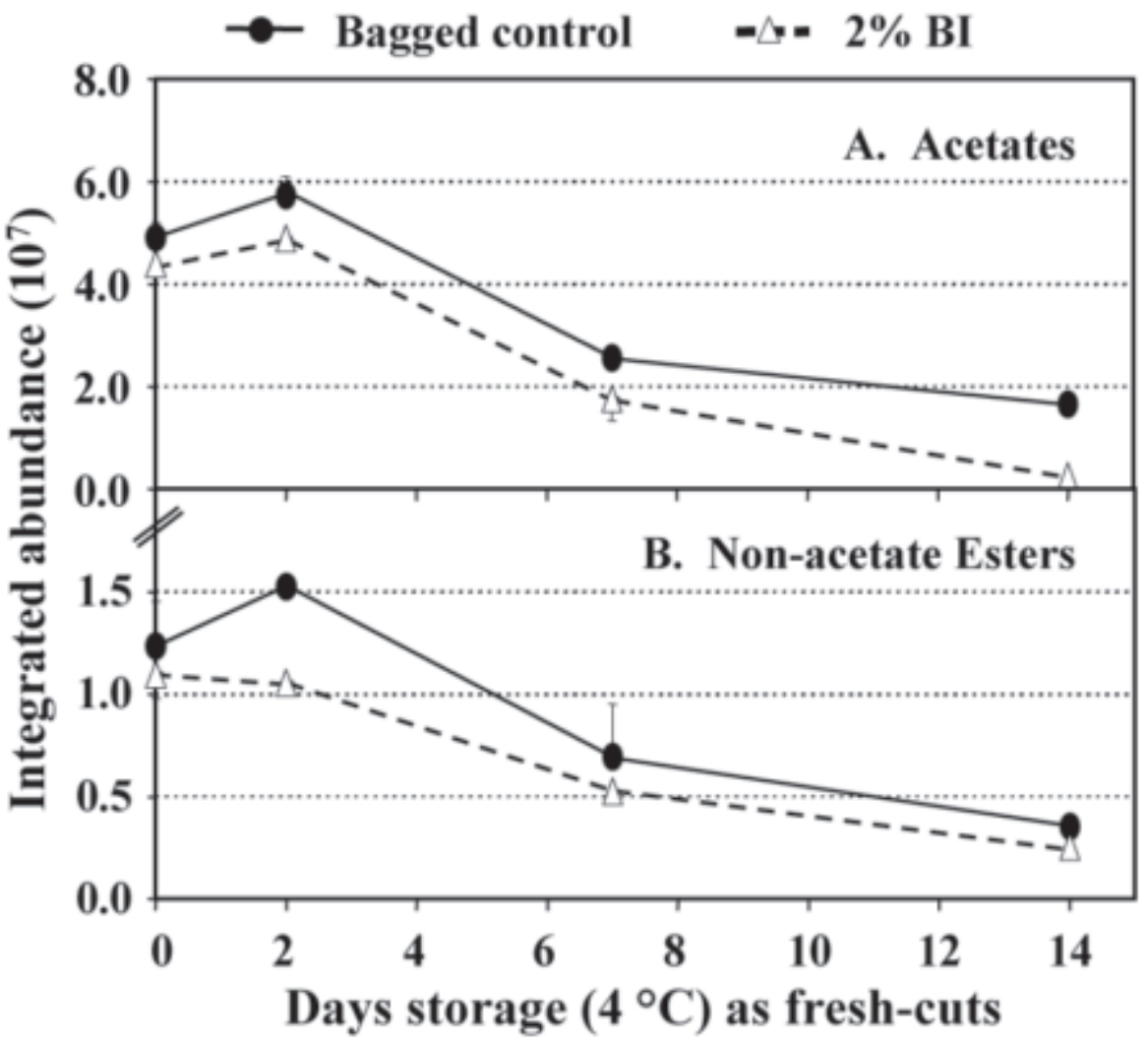

Fig. 7. Relative SPME GC-MS abundance of (A) acetate (9 of 29 compounds) and (B) nonacetate esters (10 of 29 compounds) in fresh-cut 'Gala' apple wedges plus and minus a browning inhibitor (BI) dip containing $2 \%(\mathrm{v} / \mathrm{v})$ sodium erythorbate plus $0.1 \%$ calcium chloride, sealed in poly bags stored at 4 ${ }^{\circ} \mathrm{C}$. Averages are triplicates \pm standard deviation.

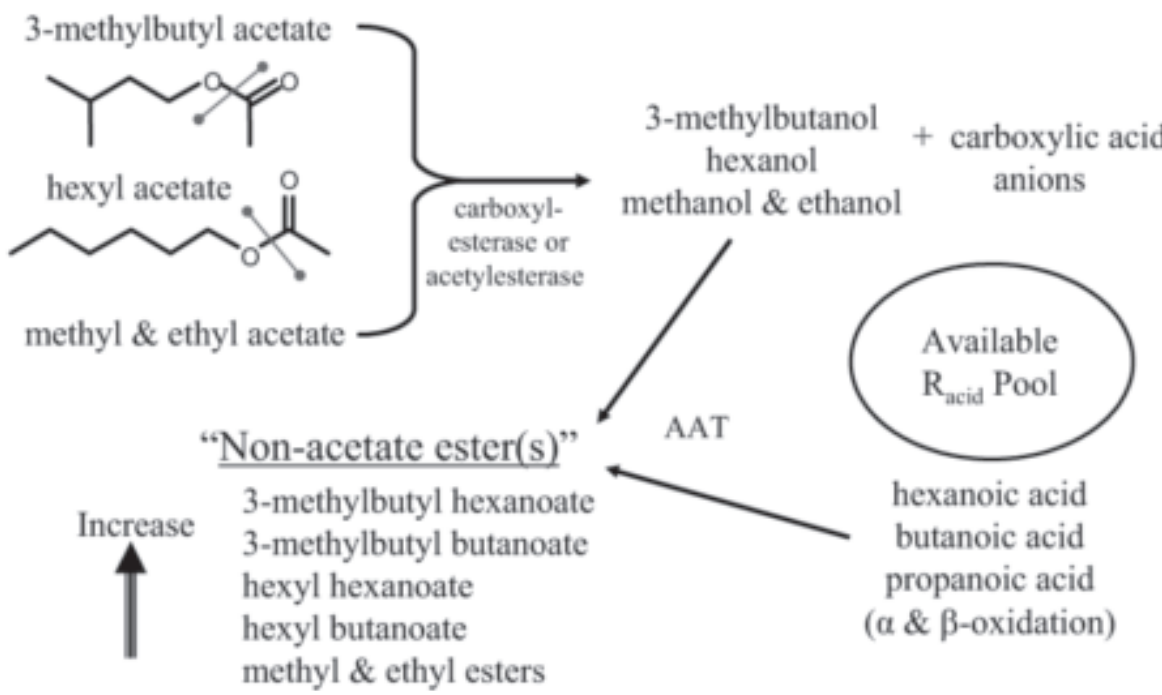

Fig. 8. Hypothetical catabolism of acetates via carboxylesterase (EC 3.1.1.1) or acetylesterase (EC 3.1.1.6) in fresh-cut melons stored under optimum $\left(4^{\circ} \mathrm{C}\right)$ conditions. The dumbbell bar indicates hydrolysis of the ester bond. from the same fields in two combined years (Fig. 5). Furthermore, the relationship must be independent of year and season since most presented examples (i.e., Figs. 3 and 5, and Table 3) are 2-years repeated studies, and also represent different years or fields when the same cultivar is displayed (Figs. 3-5). Conservation of these reported trends was also demonstrated when comparing trends of the same cultivar. For example, a high degree of parallelism was found for 'Athena' and 'Sol Real' within Figs. 4 and 5.

Honeydew. Acetates are the predominant ester type in many C. melo, such as honeydew (Fig. 6A). The ester to acetate relationship (increasing ratio during fresh-cut storage) was conserved, as nonacetate esters increased during 'Honey Brew' storage (Fig. 6B). Volatile increases during storage were also recently reported in fresh-cut honeydew (Saftner et al., 2003). Various foliar calcium treatments, applied to improve fruit firmness, and modified atmosphere packaging had only minor effects on the observed ester to acetate balance.

Apple. Ester quantity and synthesis is limited by substrate availability (Souleyre et al., 2005), and more importantly, by the activity and/or specificity of AAT (Flores et al., 2002). It is possible that there is a catabolic recycling of ester substrates in melons during fresh-cut storage. The acetate substrate pool appears to be exhausted shortly after cutting (with the exception of 2-methylpropyl acetate, derived from valine, data not shown), but nonacetate esters are continually produced. Many apple cultivars express continued ability to produce volatile esters after long-term controlled atmosphere and refrigerated storage (Fellman et al., 2000). An exception to this trend was observed in 'Gala', as both acetates (Fig. 7A) and nonacetates (Fig. 7B) decreased markedly during fresh-cut storage. Substantial ester loss occurred through storage, which was independent of tissue browning. Previously, volatile reactivation (continued ability to produce volatile esters after long-term storage) was not observed in 'Gala', and AAT levels were found to decrease appreciably during fruit storage (Fellman et al., 2000), in only this cultivar of many tested. Subsequently, a detailed analysis of the AAT level in specific fresh-cut stored melon cultivars is warranted.

Hypothetical catabolism of acetates in fresh-cut fruits. Phloem loading is responsible for sugar accumulation in melons, and sugars do not increase after harvest. In cut fruits, there may be increased oxidative reactions (e.g., $\beta$-oxidation, $\beta$-carotene breakdown and/or LOX-activity) that are required to deliver various straight chain fatty acid and cyclic moieties, which condense with alcohols to recycle esters. Hence, glycolytically derived acetyl-CoA might become the limiting factor, dictating that recycled substrates entering the acyl pool will form predominately nonacetate esters (Fig. 8). Through degradation, new substrates may be created by which additional nonacetate esters can be formed utilizing the newly formed acyl-CoA's and available alcohol pool (Figs. 2 and 8). After cutting and during product senescence, these relationships may 
be reflected by catabolic changes and volatile resynthesis, similar to previously hypothesized for apples (Knee and Hatfield, 1981). As previously postulated, esterase is likely involved in recycling of apple volatiles (Knee et al., 1989), as esterase activity in fresh-cut cantaloupe is somewhat stable during storage (Lamikanra and Watson, 2003). Perhaps esterase preferentially hydrolyzes acetate esters due to less steric hindrance at the ester bond. Nonetheless, since synthesis of esters is limited in vivo by the available substrate pool (Yahyaoui et al., 2002), break down and subsequent catabolic recycling of esters would likewise be limited by available substrates.

\section{CONCLUSION}

Aroma volatile levels increase linearly with increasing maturity in cantaloupe melons, and over-ripe fruit often have depressed levels (Beaulieu, 2006; Beaulieu and Grimm, 2001; Beaulieu et al., 2004). Overall, acetates declined substantially in stored fresh-cut apples, cantaloupes and honeydews. On the other hand, nonacetate esters generally increased during storage in all melons evaluated. AAT is not limiting during later stages of apple fruit ripening (Fellman and Mattheis, 1995), and it is unlikely that AAT activity decreases much during fresh-cut melon senescence because nonacetate esters and an occasional acetate actually increased.

Many precursor amino acids and organic acids decline in over-mature and senescent fruits (Chisholm and Picha, 1986; Muraoka and Isaka, 1985; Suni et al., 2000; Wang et al., 1993). Subsequently, production of key volatile substrates derived from the amino acids alanine, isoleucine, leucine, methionine and valine decrease as both glycolysis and the TCApathway become less active as senescence approaches. Also, after the climacteric or into senescence (the case for post-cutting of ripe fruit), once available pyruvate has metabolized into ethyl and acetate esters (Wyllie and Leach, 1990), the formation of acetate esters declines as there is no longer acetyl-CoA starting material (Fig. 2) and their concentration falls off as they are catabolized or volatize into the air.

The hypothesis is therefore put forward that recycling of esters during storage in certain fresh-cut fruits leads to an imbalance in the delicate fine balance of characteristic volatiles. This could therefore alter the overall perceived desirable flavor attributes during storage, even though overall volatile esters are still abundant.

\section{Literature Cited}

Aggelis, A., I. John, Z. Karvouni, and D. Grierson. 1997. Characterization of two cDNA clones for mRNAs expressed during ripening of melon (Cucumis melo L.) fruits. Plant Mol. Biol. 33(2):313-322.

Bareuther, C.M. 2000. Magnifying melon sales. Produce Business. (May). 60-68.

Bauchot, A.D., D.S. Mottram, A.T. Dodson, and P.J. John. 1998. Effect of aminocyclopropane1-carboxylic acid oxidase antisense gene on the formation of volatile esters in cantaloupe
Charentais melon (cv. Vedrandais). J. Agr. Food Chem. 46(11):4787-4792.

Beaulieu, J.C. 2006. Volatile changes in cantaloupe during growth, maturation and in stored freshcuts prepared from fruits harvested at various maturities. J. Amer. Soc. Hort. Sci. (in press).

Beaulieu, J.C. 2005. Within-season volatile and quality differences in stored fresh-cut cantaloupe cultivars. J. Agr. Food Chem. 53(22):8679-8687.

Beaulieu, J.C., J.M. Lea, D.A. Ingram, and K.L. BettGarber. 2004. Effect of harvest maturity on the sensory characteristics of fresh-cut cantaloupe. J. Food Sci. 69(7):S250-S258.

Beaulieu, J.C., Z. Peralta-Inga, J.M. Lea, and G. Eggleston. 2003. Sugar and organic acid variations in commercial cantaloupes and their inbred parental lines. J. Amer. Soc. Hort. Sci. 128(4):531-536.

Beaulieu, J.C. and J.M. Lea. 2003a. Aroma volatile differences in commercial orange-fleshed cantaloupes, the inbred parental lines, and stored fresh-cuts. ISHS Proceedings International Horticulture Congress, Toronto, Canada. Acta Hort. 628:809-815.

Beaulieu, J.C. and J.M. Lea. 2003b. Volatile and quality changes in fresh-cut mangos prepared from firm-ripe and soft-ripe fruit, stored in clamshell containers and passive MAP. Postharvest Biol. Technol. 30(1):15-28.

Beaulieu, J.C. and E.A. Baldwin. 2002. Flavor and aroma of fresh-cut fruits and vegetables, $\mathrm{p}$. 391-425. In: O. Lamikanra (ed.). Fresh-cut fruits and vegetables. Science, technology and market. CRC Press LLC, Boca Raton, Fla.

Beaulieu, J.C. and C.C. Grimm. 2001. Identification of volatile compounds in cantaloupe at various developmental stages using solid phase microextraction. J. Agr. Food Chem. 49(3):1345-1352.

Bett-Garber, K.L., J.C. Beaulieu, and D.A. Ingram. 2003. Effect of storage on sensory properties of fresh-cut cantaloupe varieties. J. Food Qual. 26:323-335.

Buttery, R.G., R.M. Seifert, L.C. Ling, E.L. Soderstrom, J.M. Ogawa, and J.G. Turnbaugh. 1982. Additional aroma components of honeydew melon. J. Agr. Food Chem. 30(6):1208-1211.

Chisholm, D. N. and D. H. Picha. 1986. Distribution of sugars and organic acids within ripe watermelon fruit. HortSci. 21:501-503.

Fellman, J.F., T.W. Miller, D.S. Mattison, and J.P. Mattheis. 2000. Factors that influence biosynthesis of volatile flavor compounds in apple fruit. HortScience 35(6):1026-1033.

Fellman, J.K. and J.P. Mattheis. 1995. Ester biosynthesis in relation to harvest maturity and controlled-atmosphere storage of apples, p. 149-162. In: R.L. Rouseff and M.M. Leahy (eds.). Fruit flavors: Biogenesis, characterization, and authentication. Amer. Chem. Soc., Wash., D.C.

Flores, F., F.E. Yahyaoui, G.de Billerbeck, F. Romojaro, A. Latché, M. Bouzayen, J.C.Pech, and C. Ambid. 2002. Role of ethylene in the biosynthetic pathway of aliphatic ester aroma volatiles in Charentais Cantaloupe melons. J. Expt. Bot. 53(367):201-206.

Fresh Cut. 1999b. Fresh-cut: More than 50 years of growth. Fresh Cut. 7.11, 16-18 Nov.

Gorny, J.R., R.A. Cifuentes, B. Hess-Pierce, and A.A. Kader. 2000. Quality changes in freshcut pear slices as affected by cultivar, ripeness stage, fruit size, and storage regime. J. Food Sci. 65(3):541-544.

Gorny, J.R., B. Hess-Pierce, and A.A. Kader. 1998. Effects of fruit ripeness and storage temperature on the deterioration rate of fresh-cut peach and nectarine slices. HortScience 33(1):110-113.
Harada, M., Y. Ueda, and T. Iwata. 1985. Purification and some properties of alcohol acetyltransferase from banana fruit. Plant Cell Physiol. 26:1067-1074.

Hayata, Y., T. Sakamoto, C. Maneerat, X. Li, H. Kozukz, and K. Sakamoto. 2003. Evaluation of aroma compounds contributing to muskmelon flavor in Porpak Q extracts by aroma extract dilution analysis. J. Agr. Food Chem. 51(11):3415-3418.

Hoover, M.W. 1955. Preliminary studies relating to the effect of maturity and storage treatments upon the quality of cantaloupes. Proc. Fla. State Hort. Soc. 68:185-188.

Horvat, R J. and S.D. Senter. 1987. Identification of additional volatile compounds from cantaloupe. J. Food Sci. 52(4):1097-1098.

Jordán, M.J., P.E. Shaw, and K.L. Goodner. 2001. Volatile components in aqueous essence and fresh fruit of Cucumis melo cv. Athena (muskmelon) by GC-MS and GC-O. J. Agr. Food Chem. 49(12):5929-5933.

Kemp, T.R., L.P. Stoltz, and D.E. Knavel. 1972. Volatile components of muskmelon fruit. J. Agr. Food Chem. 20(2):196-198.

Knee, M. and S.G.S. Hatfield. 1981. The metabolism of alcohols by apple fruit tissue. J. Sci. Food Agr. 32:593-600.

Knee, M., S.G.S. Hatfield, and S.M. Smith. 1989. Evaluation of various indicators of maturity for harvest of apple fruit intended for long-term storage. J. Hort. Sci. 64:413-419.

Lamikanra, O. and O.A. Richard. 2002. Effect of storage on some volatile aroma compounds in fresh-cut cantaloupe melon. J. Agr. Food Chem. 50(14):4043-4047.

Lamikanra, O. and M.A. Watson. 2003. Temperature and storage duration effects on esterase activity in fresh-cut cantaloupe melon. J. Food Sci. 68(3):790-793.

Lester, G.E. and M.A. Grusak. 2004. Field application of chelated calcium: Postharvest effects on cantaloupe and honeydew fruit quality. HortTechnol. 14(1):29-38.

McLafferty, F. 2000. Wiley registry of mass spectral data. 7th ed. Palisade Corp., Newfield, N.Y.

Muraoka, N. and T. Isaka. 1985. Changes of organic acid content and freshness of apples during storage. Rpt. Natl. Food Res. Inst. 46:27-34.

Nussbaumer, C. and B. Hostettler. 1996. New flavour compounds of Cucumis melo L., p. 70-73. In: A.J. Taylor and D.S. Mottram (eds.). Flavour science: Recent developments. Royal Soc. Chem., Cambridge, U.K.

Ogle, W.L. and E.P. Christopher. 1957. The influence of maturity, temperature, and duration of storage on quality of cantaloupes. Proc. Amer. Soc. Hort. Sci. 70:319-324.

Pérez, A.G., L.C. Sanz, and J.M. Olías. 1993. Partial purification and some properties of alcohol acyltransferase from strawberry fruits. J. Agr. Food Chem. 41:1462-1466.

Pérez, A.G., L.C. Sanz, R. Olías, J.J. Rios, and J.M. Olías. 1996. Evolution of strawberry alcohol acyltransferase activity during fruit development and storage. J. Agr. Food Chem. 44(10):3286-3290.

Pratt, H.K. 1971. Melons, p. 207-232. In: A.C. Hulme (ed.). The biochemistry of fruits and their products. Academic Press, New York.

Produce Marketing Association. 1999a. Fresh-cut produce industry overview, 1999. Produce Mktg. Assn. 1-6.

Rowan, D.D., H.P. Lane, J.M. Allen, S. Fielder, and M. B. Hunt. 1996. Biosynthesis of 2-methylbutyl, 2-methyl-2-butenyl, and 2-methylbutanoate esters in Red Delicious and Granny Smith apples using deuterium-labeled substrates. J. Agr. Food 
Chem. 44(10):3278-3285.

Saftner, R.A., J. Bai, J.A. Abbott, and Y.S. Lee. 2003. Sanitary dips with calcium propionate, calcium chloride, or a calcium amino acid chelate maintain quality and shelf stability of fresh-cut honeydew chunks. Postharvest Biol. Technol. 29:257-269.

Sapers, G.M. and R.L. Miller. 1998. Browning inhibition in fresh-cut pears. J. Food Sci. 63(2):342-346.

Schieberle, P., S. Ofner, and W. Grosch. 1990. Evaluation of potent odorants in cucumbers (Cucumis sativus) and muskmelons (Cucumis melo) by aroma extract dilution analysis. J. Food Sci. 55(1):193-195.

Shalit, M., N. Katzir, Y. Tadmor, O. Larkov, Y. Burger, F. Shalekhet, E. Lastochkin, U. Ravid, O. Amar, M. Edelstein, Z. Karchi, and E. Lewinsohn. 2001. Acetyl-CoA: Alcohol acetyltransferase activity and aroma formation in ripening melon fruits. J. Agr. Food Chem. 49(2):794-799.

Soliva-Fortuny, R.C., N. Grigelmo-Miguel, I. Hernando, M.A. Lluch, and O. Martin-Belloso. 2002a. Effect of minimal processing on the textural and structural properties of fresh-cut pears. J. Sci. Food Agr. 82(14):1682-1688.

Soliva-Fortuny, R.C., M.A. Lluch, A. Quiles, N. Grigelmo-Miguel, and O. Martin-Belloso. 2003. Evaluation of textural properties and microstructure during storage of minimally processed apples. J. Food Sci. 68(1):312-317.

Soliva-Fortuny, R.C., G. Oms-Oliu, and O. MartinBelloso. 2002b. Effects of ripeness stages on the storage atmosphere, color, and textural properties of minimally processed apple slices. J. Food Sci. 67(5):1958-1963.
Souleyre, E.J.F., D.R. Greenwood, E.N. Friel, S. Karunairetnam, and R.D. Newcomb. 2005. An alcohol acyl transferase from apple (cv. Royal Gala), MpAAT1, produces esters involved in apple fruit flavor. FEBS J. 272(12):3132-3144.

Suni, M., M. Nyman, N. A. Eriksson, L. Bjork, and I. Bjork. 2000. Carbohydrate composition and content of organic acids in fresh and stored apples. J. Sci. Food Agr. 80:1538-1544.

Toivonen, P.M.A. and J.R. DeEll. 2002. Physiology of Fresh-cut Fruits and Vegetables. p. 91-123. In: O. Lamikanra (ed.). Fresh-cut fruits and vegetables. Science, technology and market. CRC Press LLC, Boca Raton, Fla.

Ueda, Y., N. Fujishita, and K. Hachin. 1997. Presence of alcohol acetyltransferase in melons (Cucumis melo L.). Postharvest Biol. Technol. 10(2):121-126.

Wang, T., A.R. Gonzalez, and E.E. Gbur. 1993. Organic acid changes during ripening of processing peaches. J. Food Sci. 58:631-632.

Watada, A.E. and L. Qi. 1999. Quality of freshcut produce. Postharvest Biol. Technol. 15(3):201-205.

Western Farm Express. 2003. Fresh-cut vegetable, fruit sales show growth. Western Farm Express 25(21):23.

Wiley, R.C. 1994. Minimally processed refrigerated fruits and vegetables. Chapman \& Hall, London, U.K.

Wyllie, S.G. and D.N. Leach. 1990. Aroma volatiles of Cucumis melo cv. Golden Crispy. J. Agric. Food Chem. 38(11):2042-2044.

Wyllie, S.G. and D.N. Leach. 1992. Sulfur-containing compounds in the aroma volatiles of melons (Cucumis melo). J. Agric. Food Chem.
40(2):253-256.

Wyllie, S.G., D.N. Leach, and Y. Wang. 1996. Development of flavor attributes in the fruit of $C$. melo during ripening and storage, p. 228-239. In: G.R. Takeoka, R. Teranishi, P.J. Williams, and A. Kobayashi (eds.). Biotechnology for improved foods and flavors. Amer. Chem. Soc., Wash., D.C.

Wyllie, S.G., D.N. Leach, Y. Wang, and R.L. Shewfelt. 1994. Sulfur volatiles in Cucumis melo cv. Makdimon (muskmelon) aroma. Sensory evaluation by gas chromatography-olfactometry. Sulfur compounds in foods. ACS Symp. Ser. 564:36-48.

Wyllie, S.G., D.N. Leach, Y. Wang, and R.L. Shewfelt. 1995. Key aroma compounds in melons: Their development and cultivar dependence, p. 248-257. In: R.L. Rouseff and M.M. Leahy (eds.). Fruit flavors: Biogenesis, characterization, and authentication. Amer. Chem. Soc., Wash., D.C.

Yabumoto, K., M. Yamaguchi, and W.G. Jennings. 1977. Biosynthesis of some volatile constituents of muskmelon, Cucumis melo. Chem. Mikrobiol. Technol. Lebensm. 5:53-56.

Yabumoto, K., M. Yamaguchi, and W.G. Jennings. 1978. Production of volatile compounds by muskmelon, Cucumis melo. Food Chem. 3(1):7-16.

Yahyaoui, F.E.L., C. Wongs-Aree, A. Latché, R. Hackett, D. Grierson, and J.C. Pech. 2002. Molecular and biochemical characteristics of a gene encoding an alcohol acyl-transferase involved in the generation of aroma volatile esters during melon ripening. Euro. J. Biochem. 269(9):2359-2366. 